\title{
Landcare on the Poverty-Protection Interface in an Asian Watershed
}

\author{
Dennis P. Garrity ${ }^{1}$, Victor B. Amoroso, Samuel Koffa, Delia Catacutan, Gladys Buenavista, Paul Fay, and
} William Dar

ABSTRACT. Serious methodological and policy hurdles constrain effective natural resource management that alleviates poverty while protecting environmental services in tropical watersheds. We review the development of an approach that integrates biodiversity conservation with agroforestry development through the active involvement of communities and their local governments near the Kitanglad Range Natural Park in the Manupali watershed, central Mindanao, the Philippines. Agroforestry innovations were developed to suit the biophysical and socioeconomic conditions of the buffer zone. These included practices for tree farming and conservation farming for annual cropping on slopes. Institutional innovations improved resource management, resulting in an effective social contract to protect the natural biodiversity of the park. The production of fruit and timber trees dramatically increased, re-establishing tree cover in the buffer zone. Natural vegetative contour strips were installed on several hundred sloping farms. Soil erosion and runoff declined, and the buffer strips increased maize yields by an average of $0.5 \mathrm{t} / \mathrm{ha}$ on hill-slope farms. The scientific knowledge base guided the development and implementation of a natural resource management plan for the municipality of Lantapan. A dynamic grass-roots movement of farmer-led Landcare groups evolved in the villages near the park boundary, which had a significant impact on conservation in both the natural and managed ecosystems. Encroachment in the natural park was reduced by $95 \%$ in $3 \mathrm{yr}$. The local Landcare groups also restored stream-corridor vegetation. This integrated approach has been recognized as a national model for the local management of natural resources and watersheds in the Philippines. Currently, the collaborating institutions are evolving a negotiation support system to resolve the interactions between the three management domains: the park, the ancestral domain claim, and the municipalities. This integrated systems approach operated effectively with highly constrained funding, suggesting that commitment and impact may best be stimulated by a "drip-feed" approach rather than by large, externally funded efforts.

\section{INTRODUCTION}

The classical method of preserving a natural area has always been to declare it off limits and enforce exclusion. In many developing countries, enforcement often was not successful because population pressure was intense or the costs of enforcement were too high. The approach of integrating conservation and development attempts to link enforcement with compensation to the communities that are directly affected by the presence of the natural area (Wells and Brandon 1992). During the past decade, there has been an increase in the use of participatory methods in integrated watershed management projects and integrated conservation-development projects (ICDPs). However, the participatory mode is novel and complex, and such projects have little theory or experience to draw upon (Rhoades 1998).

The Sustainable Agriculture and Natural Resources Management (SANREM) Program is a global research effort that aims to develop a new paradigm for research on sustainable agriculture and natural resources management (Hargrove et al. 2000). The program takes the whole landscape and lifescape of a watershed as the basis for formulating and resolving major management issues. It includes communities and local government bodies as reviewers, partners, and implementers of research and development. The approach seems well suited to addressing some of the key methodological issues in protecting natural habitats of unique tropical biodiversity that are encountering human pressure. 
One of the three global sites in which the SANREM program has been working is the Manupali watershed on the southern border of the Kitanglad Range Natural Park in central Mindanao, the Philippines. The Biodiversity Consortium at the Philippine site is composed of collaborating organizations that include a university, NGOs, and government agencies. It was convened by the International Centre for Research in Agroforestry (ICRAF), and the work is also linked to the global program on Alternatives to Slash-and-Burn. The objective was to conduct research to develop tools and approaches that combined improved biodiversity conservation with better livelihood opportunities through agroforestry for the communities that live near the Kitanglad Range Natural Park. This paper reviews that experience. It concludes by examining the implications of an integrated natural research management approach in this context.

The consortium began its work by drawing on the lessons learned from the global experience with integrated conservation and development projects (Wells and Brandon 1992, McNeely 1995). One of the critical lessons that has emerged is that the active leadership of local people is the key. Communities near protected areas often bear substantial costs in foregone use or extraction from the protected area, yet may gain little in return. They are usually poor and quite remote from normal government services. An integrated approach with balanced attention to both enforcement and development is necessary to ensure explicit linkages between project components. To achieve the goals of protecting biological diversity and helping to improve the welfare of the people living near the protected area, it is necessary to pay explicit attention to how the rural development activities directly support the objective of protection, because some types of development initiatives may increase the pressure on the reserve. For example, road construction or growth in agricultural productivity may have this outcome under some circumstances. Introducing technologies that increase agricultural productivity may elevate land values and make it more attractive to encroach onto reserve land. Compensation to communities to promote local development may take many forms. This has often included agroforestry practices, crop intensification and irrigation, conservation farming practices, and community forestry (Wells and Brandon 1992). The objectives are to involve local people in natural resource management activities that empower them, increase their incomes, and shift their production systems in ways that better protect natural biodiversity in the agricultural landscape and reduce their need to extract resources from the protected area. For sustained protection, migration into the area must also be managed, and greater off-farm employment must be generated.

\section{INTEGRATING CONSERVATION AND DEVELOPMENT IN THE MANUPALI WATERSHED}

\section{Biodiversity value}

The Kitanglad Range Natural Park is acknowledged as one of the most important biodiversity reserves in the Philippines. It supports the richest known vertebrate fauna (mammals and birds) in the country (Heaney and Peterson 1992, Amoroso et al. 1996; L. Heaney, unpublished manuscript). It is the habitat of many endangered, endemic, rare, and economically important species of animals and plants. Heaney and Peterson (1992) observed 13 of the 14 species of birds endemic to Mindanao, including the critically endangered Philippine Eagle (Pithecophaga jefferyi). One genus of mammal is endemic to the park alone, the little known Alionycteris paucedentata.

The park is a relatively small ecosystem of approximately 50,000 ha, but it is also of exceptionally high conservation value in terms of the high endemism of the vascular flora (Amoroso et al. 1996; Pipoly and Masdulid, 1995, personal communication). This includes the endangered rootless vascular plant Tmesipteris lanceolata Dang. (Amoroso et al. 1996). The park was recently found to have the highest tree density ever reported in a tropical forest (Pipoly and Masdulid, 1995, personal communication). This combination of a small, manageable size and a rich, singular biodiversity conforms to the type of protected ecosystem that, according to Sayer (1995), ought to receive the most determined attention in tropical biodiversity protection.

\section{The watershed}

The people residing in the Manupali watershed downslope from the park exert pressure on both the natural and managed ecosystems, particularly on the remaining protected forest. In an unpublished paper presented to the National Seminar-Workshop on Environmental Education and Management in Mindanao in 1997, V. B. Amoroso noted an alarming rate of habitat destruction due to human activities, including illegal cutting of trees, overharvesting of minor products, shifting cultivation, and conversion of 
forest lands to agricultural production. The present landscape of the upper reaches of the Manupali watershed consists of essentially three belts of land:

1. the natural park, which consists mostly of pristine forested land at high altitudes $(>1200$ $\mathrm{m}$ above sea level) with few current household land claims and natural park status;

2. a zone of land surrounding the park that is managed by the Department of Environment and Natural Resources (DENR) as production forest: this is the external buffer zone of the park. This land is on the fringe of the forest and has now been converted mainly to agricultural fields interspersed with imperatadominated grassland. Encroachment here has been partly sanctioned through the expectation of social forestry stewardship contracts, with eviction no longer a tenable management option; and

3. privately owned agricultural land that is further downslope from the public DENR lands. These landholdings comprise a mosaic of agroforest, crops, and fallowed fields, with remnant forest in the steep ravines that border the streams that drain the natural park.

A Participatory Learning Landscape Appraisal and our research during the initial years (1993-1996) documented the land use practices (Banaynal 1996, Community Organizing Participatory Action Resource Development 1996). This work highlighted the urgent need to develop an integrated and sustainable bufferzone management program. The indigenous Talaandig people regard the public lands as their ancestral domain. Initial research indicated that there was a strong perception among the communities on the boundary of the park that protecting the natural biodiversity was in their own self-interest (Cairns 1996). This somewhat contrasted with the concerns of the dominant in-migrant population, which tended to emphasize resource exploitation and extraction for cash income. A major concern of the Tala-andig villagers was protection of the hydrological functions of the upper watershed for their water supplies. They were quite explicitly sensitive to the spiritual and cultural values of the forest. They attributed the current failure to protect these resources to the lack of institutional mechanisms to manage the resources in a way that explicitly recognized local needs for more secure land tenure and alternative livelihoods. The lack of state recognition of secure tenure by the households residing in the buffer zone outside the park boundaries was a critical constraint that would need to be addressed eventually.

\section{The project framework}

The project goal was to elucidate a more fundamental understanding of people-ecosystem interactions to guide development of practicable natural resource management plans and processes. The research aimed to develop the elements of a workable social contract between buffer-zone communities and the nonlocal stakeholders concerned with resource protection. We hypothesized that there were two essential conditions for sustainable buffer-zone management and biodiversity conservation in the Kitanglad Natural Park: (1) agricultural/agroforestry intensification in the buffer zone to enhance income growth, complemented by other forms of off-farm employment generation in the local and national economy, and (2) communitysupported enforcement of the boundaries of the park. Our work focused on both aspects. We investigated appropriate technical innovations suited to the biophysical and socioeconomic conditions of the buffer zone, and we studied how to induce institutional innovations that would facilitate better natural resource management. The social contract underlying the model links the provision of assistance in intensifying agriculture to local responsibility for park boundary protection.

\section{ENHANCING AGRODIVERSITY}

Agriculture is the dominant livelihood in the villages near the park, as is the case with many other protected areas in the tropics. The boundary area of the Kitanglad Range Natural Park is located at an elevation of 600 to $1700 \mathrm{~m}$, where temperate vegetable crops (including potatoes, cabbages, and tomatoes) are quite productive. Vegetable production is expected to further expand in the future. Our analysis indicated that the most likely future trajectory for farming systems in the buffer zone is toward continuous vegetable production on a portion of the farm $(0.1-1.0$ ha), with perennials (timber and fruit trees) grown on the remaining farm area, particularly on the steeper parts. A farm planning exercise with 67 families in three villages in the buffer zone (Community Organizing Participatory Action Resource Development 1996) found that the greatest interest was in establishing simple contour buffer-strip systems on the annual crop areas of the farm and increasing the area of fruit and timber tree crops on the remainder. 
The farmer-participatory research effort described below thus focused on enhancing the environment for smallholder tree production and contour buffer systems to sustain annual cropping. It involved numerous tests carried out by farmers independently, supplemented by experimental trials conducted by researchers on farmers' fields.

\section{Smallholder tree production systems}

Prior attempts to reforest the buffer zones of deforested areas in the Philippines focused on planting large blocks of trees with local wage labor paid for by the Department of Environment and Natural Resources (DENR). Such a project was implemented in the Manupali watershed during the late 1980s, prior to the Sustainable Agriculture and Natural Resource Management (SANREM) program. Like many other such top-down attempts, it failed. The plantations were burned, often by the local smallholders on whose land the trees were planted. Only a few small remnant stands now remain in the "reforested" buffer-zone area.

Research in northern Mindanao documented a major transformation toward smallholder timber tree production in this region in response to market development (Garrity and Mercado 1994). There is increasing evidence that smallholders are key to future reforestation efforts in the tropics (Garrity 1994, Pasicolan 1996). Our approach was to ensure that improved germ plasm was available for a variety of species to enhance income and reduce risk, and that best management practices suited to local farm circumstances were in place. The initial work focused on determining an appropriate mix of species of interest to farmers and testing diffusion strategies to incorporate them into farming systems. A farming systems survey (Community Organizing Participatory Action Resource Development 1996) was conducted through open-ended interviews with farmers and neighborhood groups. Several training exercises (Koffa and Garrity 2001) were also convened that fostered mutual learning between farm households and researchers. Farmers in the buffer zone and on private lands showed a strong interest in expanding the area of timber trees on their farms.

The constraints to accelerating the process were the lack of: (1) seedlings, (2) a knowledge of which species were the most profitable and of appropriate tree management, and (3) a wider range of tree germ plasm to diversify risk. Subsequently, a detailed survey was undertaken that developed a comprehensive knowledge base about the performance of multipurpose tree species at different elevations in the upper watershed (Glynn 1996). The most common timber species planted in the upper watershed were found to be Paraserianthes falcataria, Gmelina arborea, and Eucalyptus camaldulensis. Farmers observed that the eucalyptus species performed particularly well at the elevation levels in the buffer zone (Glynn 1996). Germ plasm from a range of other fast-growing timber species was introduced, with emphasis on new accessions of Eucalyptus deglupta and others. This was accompanied by a series of replicated on-farm experiments that evaluated the available commercial species in terms of their performance at different elevations. The work was complemented by attempts to domesticate a number of local species identified and used by farmers for timber (Palis 1997). Experience was also obtained, through working with farmer groups, on the effectiveness of three types of smallholder nursery systems. These activities resulted in a major acceleration in tree production in the buffer zone (see Landcare below).

\section{Enhancing conservation farming}

Continuous crop production on steep slopes in Mindanao induces annual rates of soil loss that often exceed 100-200 t/ha (Garrity et al. 1993). The installation of contour buffer strips reduces these losses by $50-99 \%$ and creates natural terraces that stabilize the landscape and facilitate further management intensification. These advantages have led to the wide promotion of contour hedgerow systems by the DENR and the Department of Agriculture. These systems are based on double rows of leguminous trees that are pruned periodically to provide green manure for the associated annual crops. Although this system has been shown to increase yields and better sustain soil fertility, adoption has been poor. Installed tree hedgerows were usually abandoned because farmers found that it took too much labor to manage them (International Centre for Research in Agroforestry 1997).

We had previously observed an indigenous buffer-strip practice that had been evolved by a few farmers at another location in the Philippines. These natural vegetative strips (NVS) were introduced into the watershed as an alternative to the recommended tree hedgerow system. NVS are created by laying out the contour lines on sloping fields, which are then allowed to revegetate with the regrowth of natural grasses 
(Garrity et al. 1993). We found that NVS are exceptionally effective in soil conservation with minimal maintenance and require no outside source of planting materials. Nelson et al. (1998) modeled longterm trends in maize yields and found that they increased after the NVS were established. On fields with NVS, maize production increased by about 0.5 $\mathrm{t} / \mathrm{ha}$. This was further supported by the experience of many farmers who claimed that the buffer strips substantially increased their yields within a few years after installation. Widespread popularization of the practice occurred through farmer-to-farmer knowledge sharing in the Landcare movement, and about 300 farmers have adopted the NVS practice on their farms in the upper watershed since 1996. In addition to the demonstrated effects on sustaining and increasing crop yields, farmers in the buffer zone also perceived that the practice strengthened their tenurial claim to the land they tilled.

Tree farming and contour buffer-strip activities had immediate potential to help farmers in the buffer zone intensify land use and increase profitability while sustaining land resources. Their widespread adoption is now supporting the institutional innovations and providing pragmatic alternatives to encroachment in the park. Current research is estimating the aggregate effects of these vegetative buffers and filters on the hydrological functions at the landscape level (van Noordwijk et al. 2001). We now turn to the process of evolving participatory institutional innovations for local natural resource management.

\section{ASSEMBLING THE ELEMENTS OF A SOCIAL CONTRACT}

The foremost policy issue impinging on local natural resource management systems is the reality of overlapping land rights and management priorities. There are three sets of overlapping management claims and systems operating in the vicinity of the park: (1) the park and production forest land administered by the Department of Environment and Natural Resources (DENR), (2) the ancestral domain claim of the Tala-andig people, and (3) the jurisdictions of the six municipalities that surround the park. These claims and systems interact geographically (Fig. 1). The policy research of the Sustainable Agriculture and Natural Resources Management (SANREM) program focused on understanding the ways in which these three overlapping jurisdictions can be reconciled, and on developing a scientific basis for management plans by the three sets of entities. The work aimed to provide options leading to a consensus that would meet the various stakeholders' concerns. We envision the development of a natural resource management system for the buffer zone of the park that is based on a holistic park management plan coordinated with an ancestral domain management plan. These need to be supported by natural resource management plans at the municipal level. We are using an integrated natural resource management framework to evolve a negotiation support system capable of resolving the interactions between these three management domains (van Noordwijk et al. 2001). The following sections review the current status of that work.

Fig. 1. Linkages between the three types of natural resource management plans in and around the Kitanglad Range Natural Park.

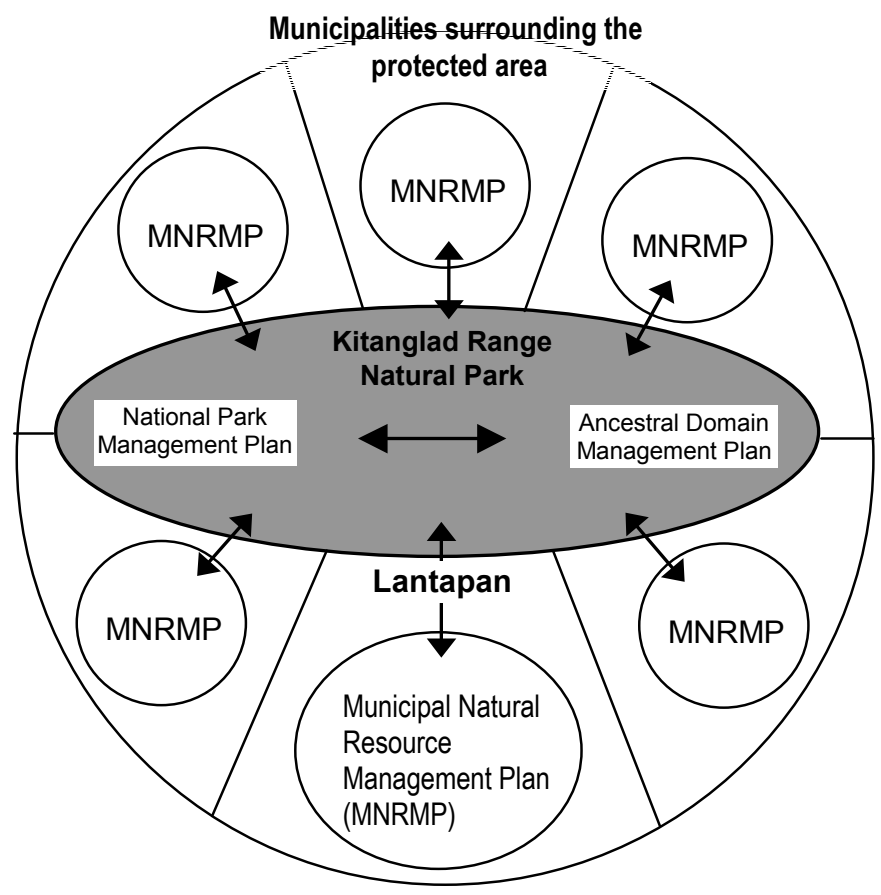

\section{Municipal model for planning natural resource management}

In late 1995, the mayor of the municipality of Lantapan committed human and financial resources to the development and implementation of such a plan, for which there was no precedent in the Philippines (Catacutan et al. 1999). The municipal government created a multisectoral Natural Resources Management Council made up of representatives of all the major sectors of the community, including 
smallholder farm households and leaders from the religious, civic, business, and education sectors. The 25 members of the council were appointed by the municipal mayor. He also established a local planning team that received support from the municipal environmental planning officer. The research team focused on assembling the knowledge needed for a scientifically based plan for managing local natural resources. The draft plan was circulated, and a series of public hearings was held. Many changes were incorporated, and the municipal council enacted the plan in early 1998. The municipal government has currently allocated $5 \%$ of the municipal budget for the implementation of the plan. In addition, 10 villages within the municipality have, through their locally elected bodies, allocated an average of $10 \%$ of their budgets to implementing activities intended to achieve objectives related to the plan. The initial impact of the plan has included a number of new policies and regulations related to resource conservation. They were proposed by the village representatives on the municipal council. Many on-the-ground activities have now been completed that have enhanced aspects of the plan related to the conservation of land, water, and biodiversity.

The technical contributions that were made to the plan by the research consortium stemmed from its work on agroforestry, conservation farming, and biodiversity conservation. For example, numerous steep ravines emanate from the Kitanglad range out into the agricultural landscape. These valleys are the least disturbed parts of the agricultural area, and they harbor diverse natural communities. They may be valuable in radiating strands of natural biodiversity outward from the protected area into the agricultural parts of the landscape. A strategy to enhance the biological integrity of the ravines was developed (Glynn 1996). A methodology to survey and map the vegetative communities of the major ravines of the Alanib River was evolved. The maps that were developed provided a basis for identifying the hot spots where changes in land management practices were needed to protect stream water quality and riparian biodiversity. A local volunteer water-watch organization has been monitoring the water quality of the major streams. Its results pointed to serious biological contamination of the water supplies of several communities. Based on this information, a ravine habitat management component was incorporated into the municipal natural resource management plan. The communities have now been actively replanting trees in the degraded stream-bank areas through voluntary initiatives and efforts.
The Lantapan experience represents a significant advance in municipality-led and participatory local natural resource management planning. In 1998, the DENR recognized the Lantapan experience as a national model for natural resource management planning in the Philippines Strategy for Improved Watershed Resources Management (Department of Environment and Natural Resources 1998). The model is now being implemented in other municipalities in Bukidnon and in other provinces throughout the country. It is a significant step in the devolution of planning and management for natural resource protection to the local level, and a major shift from traditional top-down planning approaches toward participatory, multisectoral planning and researchbased decision making.

\section{The Landcare movement mobilizes grass-roots conservation}

The villages that immediately surround the protected area are on the conservation interface. They are embedded physically in the competing jurisdictions of the local municipality, the state forest land claimed by the DENR, and the ancestral domain claimed by the original inhabitants. Ultimately, the success of natural resource conservation depends on the initiative, active involvement, and support of the local residents. This requires a stronger conservation ethic at the community level, the adoption and adaptation of conservation-oriented and more productive farming practices, and collaboration between villagers and the park administration in boundary enforcement (Garrity 1995). Our hypothesis was that village-level organizations for knowledge sharing and community action are fundamental to addressing these natural resource management challenges.

A movement of farmer-led knowledge-sharing organizations had evolved in the nearby municipality of Claveria in a watershed in northern Mindanao. This Landcare movement (Mercado et al. 2000) was initiated by small, self-governing groups of farmers. Their initial objective was to diffuse agroforestry practices among upland farming neighborhoods. Their interest was in learning and sharing experiences with new technologies that increased income while conserving natural resources. The groups formed themselves at the neighborhood (subvillage) level. The agenda later expanded to many other aspects of community action for local natural resource management, such as fire control, soil conservation policies, and riparian protection. Today, more than 
3000 households in Claveria are members of the 145 chapters of the Landcare Association. They have initiated more than 300 nurseries for fruit and timber trees and are actively disseminating conservation technologies to fellow farmers via farmer-to-farmer contacts. More than 1500 farms in Claveria have adopted contour buffer-strip systems on their sloping agricultural lands through these voluntary exchanges. As the movement grew, it began to attract strong support from the local government units at the village and municipal levels. It received technical support from NGOs and Department of Agriculture extension agents (Mercado et al. 2000). Landcare is now active in 15 municipalities in five Philippine provinces.

The Landcare approach was introduced in Lantapan in 1998 through exchange visits by numerous Lantapan farmers and civic leaders to Claveria; they also networked with the local government and with municipal agricultural extension agents. The movement grew rapidly. Currently, there are more than 45 Landcare groups in Lantapan, with a total of more than 800 members. Most of these groups live in the villages near the park boundary. The neighborhood groups coalesced into village chapters. Representatives of the chapters meet monthly as part of the municipal Landcare Federation. They share new information and ideas that have emerged in the various groups, and together they plan larger-scale community activities. The municipal and village governments actively support the Landcare groups through annual budgetary allocations.

The chapters have stimulated the development of more than 40 nurseries for timber and fruit trees and fostered the adoption of contour buffer strips on several hundred farms. They have begun community-wide environmental protection by assisting with the planting of thousands of trees to protect the riparian buffer zone along the Kalasihan River after the local water-watch monitoring group showed that it was experiencing the most severe pollution problems in the area. Municipality-wide environmental awareness has increased during the past $3 \mathrm{yr}$ as a result of the intensified activities of the Landcare movement and the support of the municipal and village government units. The effects of these developments on the protection of the natural park are now clearly evident. Previously, the frequency of encroachment for extraction or slash-and-burn farming in the park was completely out of control, with hundreds of episodes occurring each year. The annual number of park encroachment incidents during the past $3 \mathrm{yr}$ has declined by about 95\% (F. Mirasol, Park Director, personal communication). This was attributed to enhanced collaboration between the villagers, the park administration, and the municipal governments through the institutional innovations described above.

A legal system of secure land tenure for the farm populations inhabiting the buffer zone has yet to be fully devised and implemented. In the meantime, however, the Landcare experience indicates that the residents perceive that regulations to more formally recognize their local tenurial rights will be forthcoming. Evidence of this is abundant in the types of long-term investments in soil conservation and tree production systems that are rapidly being adopted. The Landcare movement has significantly increased the social and political capital of the residents. It has been a contributing factor to positive developments in local natural resource management.

Douthwaite et al. (2001) have pointed out that, in complex environments, integrated natural resource management (INRM) interventions must be able to foster and motivate the innovative potential of local people. They note that a grass-roots community development model can lever enormous amounts of creative talent. This has striking implications for INRM. Our ongoing evaluation of the Landcare experience in Mindanao, combined with locally led natural resource management planning and implementation at the municipal level, suggests that it embodies the creation of these types of human and social capital.

\section{DISCUSSION}

This paper has reviewed an approach to integrating conservation and development that links the protection of biodiversity with the development and adoption of improved agroforestry farming methods and with innovations in local institutions by the communities that are directly affected by the presence of a natural park. The objectives were to develop tools and approaches that combined improved biodiversity conservation with better livelihood opportunities, to increase local capacity to manage natural resources, and to apply the tools to solve a set of complex natural resource management challenges. To achieve the goals of protecting biological diversity and helping to improve the welfare of the people living near the protected area, it was necessary to pay explicit attention to how these rural development activities directly supported the objective of protection. 
Significant progress has now been achieved in assembling the elements for an effective social contract to protect the natural biodiversity of the Kitanglad Range Natural Park while also improving the livelihoods of the communities on the park boundary. As Fig. 2 shows, the work can be seen in the context of an integrated natural resources management (INRM) framework (Izac and Sanchez 2001). This framework is an intellectual and methodological successor to the farming systems research framework. However, it places more emphasis on the links and trade-offs between enhanced biological productivity, ecosystem integrity and resilience, and human well-being. There is significant

Fig. 2. Elements of the approach in the Manupali watershed to alleviate poverty and protect environmental services in an integrated antural resource amangement reseach framework.

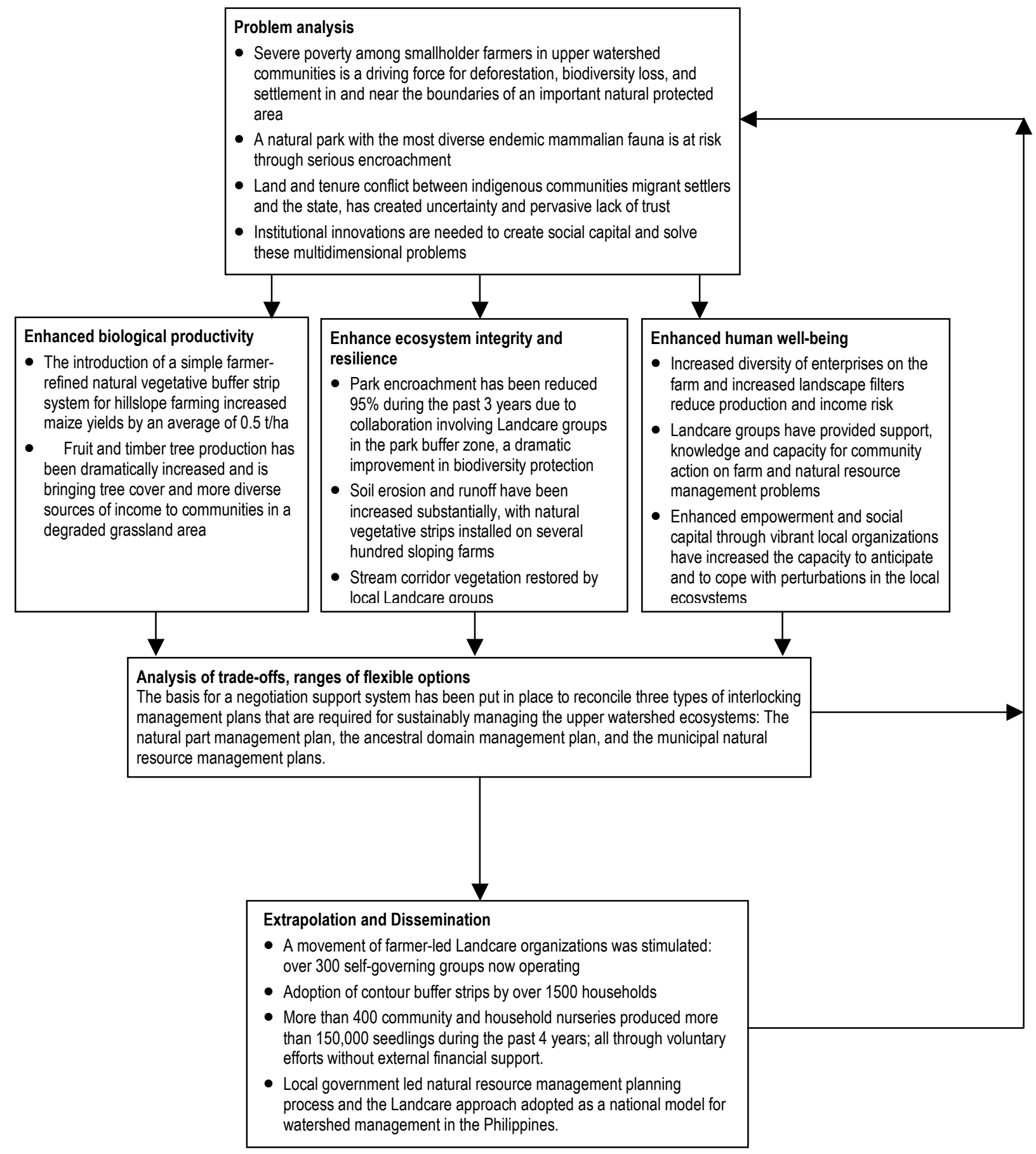


evidence that the integrated approach creates an effective linkage between development and conservation. As a result of strong initiatives and support for the planning and implementation of natural resource management at the local level and of the efforts of the grass-roots Landcare farmer groups, a conservation ethic has been spreading through all segments of the community. Strong support for a wide range of environmental concerns is now common among migrant households, religious and educational leaders, local politicians, the staff of the local government units, and the commercial agribusiness community, in addition to the original Tala-andig inhabitants.

Significant progress has now been achieved in assembling the elements for an effective social contract to protect the natural biodiversity of the Kitanglad Range Natural Park while also improving the livelihoods of the communities on the park boundary. As Fig. 2 shows, the work can be seen in the context of an integrated natural resources management (INRM) framework (Izac and Sanchez 2001). This framework is an intellectual and methodological successor to the farming systems research framework. However, it places more emphasis on the links and trade-offs between enhanced biological productivity, ecosystem integrity and resilience, and human well-being. There is significant evidence that the integrated approach creates an effective linkage between development and conservation. As a result of strong initiatives and support for the planning and implementation of natural resource management at the local level and of the efforts of the grass-roots Landcare farmer groups, a conservation ethic has been spreading through all segments of the community. Strong support for a wide range of environmental concerns is now common among migrant households, religious and educational leaders, local politicians, the staff of the local government units, and the commercial agribusiness community, in addition to the original Tala-andig inhabitants.

The sensitivity of the wider community to the environmental and religious values of the Tala-andig has also broadened and deepened. Biodiversity protection is now accepted as a local responsibility by a broad segment of the local society beyond the ancestral communities. It is now pursued with a strong civic pride. Some of the key success factors identified are a strong consortium of both research and development institutions, and local government entities committed to an integrated systems approach.
This group evolved with a common vision and the patience to nurture that vision under highly constrained funding conditions. Indeed, the funding constraints may have been a blessing. Increasingly, it is observed that higher levels of commitment and impact for integrated conservation and development may be stimulated by a "drip-feed" approach rather than by large, externally funded efforts.

The challenge yet to be resolved is the reconciliation of the ancestral domain claim with the park jurisdiction and with the need for greater tenurial security among immigrant settlers in the buffer zone. Similar manifestations of these upland tenurial issues are observed in various forms throughout Southeast Asia. A negotiation support system is being developed to facilitate the resolution of such conflicts (see van Noordwijk et al. 2001). These tools are being developed through work at three key watersheds in the region. In addition to the Manupali watershed in the Philippines, the other two are located at Sumberjaya, Indonesia, and Mae Chaem, Thailand.

Responses to this article can be read online at:

http://www.consecol.org/Journal/vol6/iss 1/art12/responses/i ndex.html.

\section{LITERATURE CITED}

Amoroso, V. B., F. Acma, and H. Pava. 1996. Diversity, status and ecology of Pteridophytes in three forests in Mindanao. Pages 55-60 in J. M. Camus and R. J. John, editors. Pteridology in perspective. Royal Botanic Gardens, Kew, London, UK.

Banaynal, R. A. 1996. COPARD 2: NECI annual progress report. Network for Environmental Concerns, Cagayan de Oro City, The Philippines.

Cairns, M. F. 1996. Ancestral domain and national park protection: a mutually supportive paradigm? A case study of the Mt. Kitanglad Range National Park, Bukidnon, Philippines. Page 15 in Summary Report of a National Workshop on Buffer Zone Management and Agroforestry. International Centre for Research in Agroforestry, Bogor, Indonesia.

Catacutan, D., D. P. Garrity, and F. S. Mirasol. 1999. Reinventing protected area management: from curing to preventing. Working Paper. International Centre for Research in Agroforestry, Los Banos, The Philippines.

Community Organizing Participatory Action Resource Development. 1996. Community Organizing Participatory Action Resource Development research: terminal report 
(cycle 1). Network for Environmental Concerns, Cagayan de Oro City, The Philippines.

Department of Environment and Natural Resources. 1998. The Philippines strategy for improved watershed resources management. Forest Management Bureau, Deptartment of Environment and Natural Resources, Quezon City, The Philippines.

Douthwaite, B., N. de Haan, V. Manyong, and D. Keatinge. 2001. Blending "hard" and "soft" science: the "follow-the-technology" approach to catalyzing and evaluating technology change. Conservation Ecology 5(2): ZZ. [online] URL: http://www.consecol.org/vol5/iss2/artZZ.

Garrity, D. P. 1994. The importance of agroforestry and ICRAF's mission in Southeast Asia. Pages 107-115 in Present situation, problems, prospects and practical implementation program of education and research on forestry for sustainable agriculture and natural resources conservation in Asia. University of Tsukuba, Tsukuba, Japan.

Garrity, D. P. 1995. Improved agroforestry technologies for conservation farming: pathways toward sustainability. Pages 145-168 in Proceedings of the International Workshop on Conservation Farming for Sloping Uplands in Southeast Asia: Challenges, opportunities and prospects. International Board for Soils Research and Management, Bangkok, Thailand.

Garrity, D. P., and A. Mercado. 1994. Reforestation through agroforestry: market-driver smallholder timber production on the frontier. Pages 265-268 in J. B. Raintree and H. A. Francisco, editors. Marketing of multipurpose tree products in Asia. Winrock International, Morrilton, Arkansas, USA.

Garrity, D. P., D. M. Kummer, and E. S. Guiang. 1993. The Philippines. Page 549-624 in Agricultural sustainability and the environment in the humid tropics. National Academy, Washington, D.C., USA.

Glynn, C. 1996. Overcoming constraints to agroforestry adoption in tropical highlands: an investigation of performance by elevation patterns for some commonly grown timber species in the Manupali Watershed, Bukidnon, Philippines. Thesis. University of London, London, UK.

Hargrove, W., D. P. Garrity, R. E. Rhoades, and C. L. Nelly. 2000. A landscape/lifescape approach to sustainability in the tropics: the experience of the SANREM CRSP at three sites. Pages 209-222 in R. Lal, editor. Integrated watershed management in the global ecosystem. CRC Press, Boca Raton, Florida, USA.
Heaney, L., and A. F. Peterson. 1992. Inventory of the vertebrates of Mt. Kitanglad Nature Park; final report. PUBLISHER NAME, CITY, COUNTRY.

International Centre for Research in Agroforestry. 1997. Annual report for 1996. ICRAF, Nairobi, Kenya.

Izac, A. M. N., and P. A. Sanchez. 2001. Towards a natural resource management paradigm for international agriculture: the example of agroforestry research. Agroforestry Systems 69:5-25.

Koffa, S. N., and D. P. Garrity. 2001. Grassroots empowerment and sustainability in the management of critical natural resources: the Agroforestry Tree Seed Association of Lantapan. Pages 197-217 in I. Coxhead and G. Buenavista, editors. Seeking sustainability: challenges of agricultural development and environmental management in a Philippine watershed. Philippine Council for Agriculture, Forestry, and Natural Resources Research and Development. Los Banos, The Philippines.

McNeely, J. A. 1995. Partnerships for conservation: an introduction. Pages 1-12 in J. A. McNeely, editor. Expanding partnerships in conservation. Island Press, Washington, D.C., USA.

Mercado, A. R., Jr., M. Patindol, and D. P. Garrity. 2000. The landcare experience in the Philippines: technical and institutional innovations for farming. Pages 236-244 in Changing landscapes - changing futures: proceedings of the International Landcare Conference, March 2000. MurrayDarling Basin Commission, Victoria, Australia.

Nelson, R. A., R. A. Cramb, and M. A. Mamicpic. 1998. Erosion/productivity modelling of maize farming in the Philippine uplands. Part 3. Economic analysis of alternative farming methods. Agricultural Systems 58(2):165-183.

Palis, H. 1997. Domestication initiatives of indigenous tree species in Mt. Kitanglad; final report of SANREM Phase 1. International Centre for Research in Agroforestry, Bogor, Indonesia.

Pasicolan, P. 1996. Tree growing on different grounds: an analysis of local participation in contract reforestation in the Philippines. Centre for Environmental Science, Leiden, The Netherlands.

Rhoades, R. 1998. Participatory watershed research and management: where the shadow falls. Gatekeeper Series, Number 81. International Institute for Environment and Development, London, UK.

Sayer, J. A. 1995. Science and international nature conservation. Occasional Paper Number 4. Center for International Forestry Research, Bogor Barat, Indonesia. 
van Noordwijk, M., T. R. Tomich, and B. Verbist. 2001. Negotiation support models for integrated natural resource management in tropical forest margins. Conservation Ecology 5(2): ZZ. [online]

URL: http://www.consecol.org/vol5/iss2/artZZ.

Wells, M., and K. Brandon. 1992. People and parks: linking protected area management with local communities. World Bank/World Wildlife Fund/USAID, Washington, D.C., USA. 